\title{
Tuberculosis control in Europe and international migration
}

\author{
Report of a European Task Force prepared by H.L. Rieder*, J-P. Zellweger**, \\ M.C. Raviglione ${ }^{+}$, S.T. Keizer++, G.B. Migliorit
}

Tuberculosis control in Europe and international migration. H.L. Rieder, J-P. Zellweger, M.C. Raviglione, S.T. Keizer, G.B. Migliori. OERS Journals Ltd 1994.

ABSTRACT: This is a consensus-based position paper of a Task Force, comprising representatives of nongovernmental and governmental organizations in the European Region of the International Union Against Tuberculosis and Lung Disease and the World Health Organization, on tuberculosis control in the countries of Europe and international migration.

Tuberculosis among the foreign population entering European countries represents an increasing and important proportion of all tuberculosis cases reported in these countries. Adequate surveillance systems allow the identification of population segments at an excess risk of tuberculosis compared to the general population. Among groups of foreigners with a risk considerably exceeding that of the general population, screening for tuberculosis and infection with $M$. tuberculosis yields a large number of persons in many countries who can benefit from curative and preventive interventions.

The Task Force recommends that European countries: 1) have notification systems based on both mandatory laboratory and physician reports of tuberculosis cases, to allow identification of population segments at an excess incidence of tuberculosis compared to the general population; 2) consider screening of high incidence and prevalence groups among the entering foreign population for tuberculosis and infection with $M$. tuberculosis amenable to curative and preventive intervention; 3) utilize existing governmental and nongovernmental organizations to provide culturally and socially sensitive services to ensure proper follow-up and implementation of interventions; 4) provide comprehensive curative and preventive services to treat tuberculosis; and 5) evaluate efficiency and efficacy of screening procedures on an ongoing basis.

Eur Respir J., 1994, 7, 1545-1553.
*Tuberculosis Section of the International Union Against Tuberculosis and Lung Disease, Paris, France. **European Region of the International Union Against Tuberculosis and Lung Disease, Fribourg, Switzerland. +Tuberculosis Programme, World Health Organization, Geneva, Switzerland. ${ }^{++}$Tuberculosis Department, Municipal Health Service, Amsterdam, The

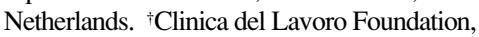
Care and Research Institute, Tradate, Italy.

Correspondence: H.L. Rieder

Tuberculosis Section of IUATLD

Reichenbachstr. 15

3004 Bern

Switzerland.

Keywords: Migration, screening, tuberculosis

Received: April 111994 Accepted for publication April 201994

Reprint requests: International Union Against Tuberculosis and Lung Disease, 68, Boulevard Saint-Michel, 75006 Paris, France.

or

World Health Organization, Tuberculosis Programme, 1211 Geneva 27, Switzerland.
One of the most prominent features of population dynamics is the observation that traditional migration patterns are undergoing changes. International migration imposes on host countries the responsibility to develop an understanding of health care needs of migrants in general [1], and tuberculosis in particular [2,3]. Political and economic turmoil in their countries of origin has forced people from countries with a high incidence of tuberculosis to seek asylum and refuge in countries where tuberculosis has come close to its elimination phase. A recent analysis of secular trends of tuberculosis in Western Europe has indicated that an increasing proportion and number of cases notified annually in various countries are found among persons of foreign nationality [4] (table 1). There are sufficient indications to conclude that international migration from countries with high incidence of tuberculosis to countries with low incidence will continue.

Tuberculosis was the most prominent killer in Europe during the last century. The number of cases has rapidly declined throughout this century. In Europe today, tuberculosis is increasingly found among identifiable seg- ments of the population, with an incidence that is clearly in excess of that found in the general population. A workshop held in Wolfheze in 1990 indicated the need to identify such groups, and to develop targeted intervention strategies to hasten progress towards elimination of tuberculosis from Europe [5].

There is no convincing evidence, up to now, that tuberculosis among the immigrant population measurably affects the epidemiology among the indigenous population. One study in Montreal has shown that the prevalence of infection with Mycobacterium tuberculosis among Canadian-born school children did not differ between areas with a high proportion of foreign immigrants from areas with a low proportion [6]. Furthermore, in the United States, a country with one of the most heterogenous populations in the world, the epidemiology of tuberculosis has for a long time been very different between the majority population and various ethnic minorities [7], indicating that a high tuberculosis incidence in one population segment does not necessarily affect that in another. That tuberculosis is not easily transmissible is evident from numerous studies among close and other 
Table 1. - Tuberculosis notifications in the indigenous and foreign population in selected countries of Europe*

\begin{tabular}{|c|c|c|c|c|c|c|c|c|c|c|}
\hline \multirow[t]{2}{*}{ Country } & \multicolumn{2}{|c|}{$\begin{array}{c}\text { Total reported } \\
\text { cases }\end{array}$} & \multicolumn{3}{|c|}{$\begin{array}{c}\text { Cases among } \\
\text { indigenous population }\end{array}$} & \multicolumn{3}{|c|}{$\begin{array}{l}\text { Cases among } \\
\text { foreigners }\end{array}$} & \multirow[t]{2}{*}{$\begin{array}{l}\text { Crude rate ratio } \\
\text { foreign:indigenous }\end{array}$} & \multirow[t]{2}{*}{$\begin{array}{r}\text { Year of } \\
\text { report }\end{array}$} \\
\hline & $\mathrm{n}$ & Rate $^{+}$ & $\mathrm{n}$ & $\%$ & Rate $^{+}$ & $\mathrm{n}$ & $\%$ & Rate $^{+}$ & & \\
\hline Belgium & 1,335 & 13.3 & 932 & 70 & 10.2 & 403 & 30 & 43.7 & 4.3 & 1992 \\
\hline Finland & 695 & 13.7 & 651 & 94 & 13.0 & 44 & 6 & 95.1 & 7.3 & 1992 \\
\hline France $^{\dagger}$ & 8,605 & 15.2 & 5,421 & 63 & 10.2 & 2,159 & 24 & 60.0 & 5.9 & 1992 \\
\hline Germany & 14,113 & 17.4 & 10,181 & 72 & 13.5 & 3,932 & 28 & 66.8 & 4.9 & 1992 \\
\hline Netherlands & 1,465 & 10.1 & 720 & 49 & 5.0 & 745 & 51 & 103.2 & 20.6 & 1992 \\
\hline Northern Ireland & 108 & 6.8 & 104 & 96 & 6.6 & 4 & 4 & 21.3 & 3.2 & 1992 \\
\hline Norway & 285 & 6.7 & 173 & 61 & 4.2 & 112 & 39 & 57.2 & 13.5 & 1992 \\
\hline Slovenia & 604 & 29.4 & 489 & 81 & 24.5 & 115 & 19 & 59.6 & 2.4 & 1992 \\
\hline $\begin{array}{l}\text { Spain } \\
\text { (Catalonia only) }\end{array}$ & 3,298 & 54.1 & 3,066 & 93 & 51.0 & 232 & 7 & 258.0 & 5.1 & 1992 \\
\hline Sweden & 610 & 7.1 & 280 & 46 & 3.6 & 330 & 54 & 40.5 & 11.3 & 1992 \\
\hline Switzerland & 987 & 14.2 & 516 & 52 & 9.2 & 471 & 48 & 35.2 & 3.8 & 1992 \\
\hline
\end{tabular}

*: different definitions were used in different countries to include "foreigners"; in some countries, this included persons holding a foreign passport, in others persons born to foreign parents, or persons born in a foreign country, and other definitions; ${ }^{+}$: rates are per 100,000 population; ${ }^{\dagger}$ : numbers among the indigenous and the foreign population do not add up to total, because citizenship

contacts. These studies have consistently shown that those at highest risk of acquiring infection from an undiscovered infectious source are those living in closest proximity [8-10]. Refugees, asylum seekers, and foreign workers are often forced to live under crowded conditions, in an environment that is conducive to transmission of tubercle bacilli. Because of multiple barriers, immigrants may have poorer access to health care facilities, and diagnosis and treatment of infectious tuberculosis may be unduly delayed. Appropriate steps to be taken to reduce such barriers would require interpreters and provision of free tuberculosis treatment. Because of the public health threat that untreated tuberculosis can impose, ways must also be found for entitlement to treatment of illegal foreigners without fear of persecution.

The purpose of this paper is to present activities that are currently undertaken in various countries to address the problem, and to formulate principles for a more active policy that could be acceptable as a basis for national governmental and nongovernmental organizations alike to control tuberculosis. This position paper is to be understood as a direct extension of the general strategy outlined during the workshop held in Wolfheze in 1990 [5].

\section{Definitions of terms}

To base the discussion on a common language, operational definitions of the following terms are proposed: 1. A "foreigner" is defined as a person who is not a national of the state in which he or she is present.

2. A "foreign-born citizen" is defined as a person who is a national of the state in which he or she is present, but who was born in another country.

3. An "immigrant" is defined as a foreigner legally admitted and expected to settle in a host country.

4. A "migrant worker" is defined as a person who is to be engaged, is engaged, or has been engaged in a remunerative activity in a state of which he or she is not a national.
5. A "refugee" is defined as a person who meets the refugee definition of the 1951 Convention related to the Status of Refugees and its 1967 Protocol, or of other relevant regional instruments.

6. An "asylum seeker" is defined as a person wishing to be admitted to a country as a refugee, and awaiting decision on his or her application for refugee status under relevant international instruments.

7. An "illegal foreigner" is defined as a person whose entry, stay, or work in a host country is illegal.

8. "Infection with M. tuberculosis" is defined as the subclinical, latent infection with tubercle bacilli (by common understanding including all three species of the $M$. tuberculosis complex), manifested by a significant tuberculin skin test reaction without any sign of clinically and/or bacteriologically and/or radiologically active disease.

9. "Tuberculosis" refers to clinically and/or bacteriologically and/or radiologically active disease.

10. "Elimination phase" is said to have been achieved when the incidence of all forms of active tuberculosis has fallen below 1 per 100,0000 population per year [5]. 11. "High incidence groups" are population segments with an incidence clearly in excess of that in the general population [5].

12. "Preventive chemotherapy" is defined as the treatment of subclinical, latent infection with M. tuberculosis to prevent progression to active tuberculosis.

13. "Recent infection" is used here synonymously with "tuberculin skin test conversion", and is defined as a significant skin test reaction after documentation of a negative tuberculin skin test within the preceding 2 yrs. For practical purposes children with a significant tuberculin skin test reaction size under the age of $15 \mathrm{yrs}$, without Bacille Calmette-Guérin (BCG) vaccination, and close contacts of sputum smear-positive cases under the age of 50 yrs with a significant tuberculin skin test, are also included in this group.

14. "Fibrotic lesions" are defined as well-delineated radiographic lesions compatible with healed tuberculosis. 


\section{The epidemiological situation in Europe}

The epidemiology of tuberculosis both in Western and Eastern Europe has recently been examined [4, 11]. In all European countries, tuberculosis has markedly decreased in this century. In recent years, the decline in tuberculosis has slowed, and there may even have been an increase, in several European countries. The number of tuberculosis cases in the foreign population has been growing and constitutes a significant proportion of the overall incidence of tuberculosis in several countries (table 1). As tuberculosis has become less frequent among the indigenous population of Europe, specific groups, such as foreigners from certain countries with a higher than the average country-specific notification rate, require particular attention $[5,12]$.

\section{Current control measures in Europe}

Almost uniformly in Europe, tuberculosis control is generally based on passive case-finding and treatment of newly discovered cases, supplemented in part by contact tracing, and provision of preventive therapy to those discovered during such activities as being recently infected [5]. A survey among European countries has revealed that a considerable number of countries have provisions for screening groups of immigrants and other foreigners seeking entrance to a country by means of radiographic examination and, occasionally, by tuberculin skin testing also (table 2). The inclination to provide preventive chemotherapy, according to this survey, ranges from complete abstinence to aggressive implementation. These differences are partially explained by differences in the interpretation, not of the efficacy but of the efficiency, in providing preventive chemotherapy to infected but healthy persons. Furthermore, the widespread use of BCG vaccination in Europe compromises efficient discrimination between infected and noninfected persons. In some Eastern European countries, shortages of drugs for curative treatment and other serious programme constraints [11] may preclude the use of preventive therapy, as it will clearly rank lower in priority of intervention strategies than treatment of overt disease.

\section{Elements of surveillance}

In most European countries, tuberculosis is a notifiable disease (table 2). Although common wisdom dictates that tuberculosis is traditionally better reported by physicians than most other notifiable diseases, data on the completeness of reporting are apparently scarce. Only a few countries require information on ethnic origin or legal status of notified cases of tuberculosis. In some countries, collection of such information is illegal. There are fewer laboratories capable of identifying tubercle bacilli than there are physicians who potentially see suspects. Thus, some countries have adopted a policy of requiring (or at least requesting) both physicians and laboratories to report suspects or culture-confirmed cases, respectively, [4, 13, 14]. Where the legal framework permits nominal data, cases reported only by laboratories can then be followed up and the physician in charge requested to provide demographic information that is deemed epidemiologically necessary. Such information should clearly allow for identification of groups at particularly high risk of developing tuberculosis.

A minimal set of information required to make rational decisions should always include the following, hierarchically listed:

1. Date of birth

2. Gender

3. Site of disease

4. Bacteriological status

5. Country of birth (and/or citizenship)

6. History of previous antituberculosis chemotherapy These variables may be supplemented by others (such as year of immigration for cases among foreigners, other diagnostic studies undertaken, etc.), depending on feasibility and intent of analysis. Nevertheless, with these variables, it will be possible to identify groups having an incidence in excess of that observed in the general population, and thus provide guidance for which population segments a screening programme might be rewarding. It is apparent that individual, not aggregate, data need to be collected to allow for meaningful analysis.

\section{Targeted screening and methods}

\section{General considerations on screening}

Before embarking on a screening programme for tuberculosis among foreigners entering a country, some general considerations about the objectives and consequences of screening are deemed necessary.

The objective of medical screening is to discover conditions among patients suitable for early preventive or curative intervention, which are not sufficiently symptomatic to induce the patient to seek medical help on his or her own. The condition being screened for must be sufficiently prevalent for the screening procedure to be effective; must have an easily agreed diagnostic criterion; must have a known natural history; and must be amenable to definitive intervention [15]. Furthermore, whenever a screening programme is initiated, the data generated must be collected and analysed to allow a continuous evaluation of the yield of screening and a comparison with the costs of such a programme.

It must be ensured that the condition that is discovered through screening gets prompt and definitive medical attention, including patient counselling, which in itself needs to result in restoration of health or in a clearly targeted intervention. In the case of tuberculosis control, transmission of $M$. tuberculosis must definitively be interrupted or prevented from ever occurring.

Each screening tool has its predefined operating characteristics, i.e., sensitivity and specificity. The predictive value of a positive finding, i.e. the probability that 
Table 2. - Tuberculosis control among foreigners; in all countries, some refugees might be screened before entrance, if the medical procedures are organized through the International Organization for Migration

\begin{tabular}{|c|c|c|c|c|c|c|}
\hline Country & $\begin{array}{l}\text { Screening } \\
\text { system }\end{array}$ & $\begin{array}{l}\text { Method used for } \\
\text { screening }\end{array}$ & $\begin{array}{l}\text { Target group for } \\
\text { screening }\end{array}$ & Time of screening & $\begin{array}{l}\text { Utilization of } \\
\text { preventive } \\
\text { chemotherapy }\end{array}$ & $\begin{array}{l}\text { Notification } \\
\text { system }\end{array}$ \\
\hline Austria & Active & $\begin{array}{l}\text { Radiography } \\
\text { Tuberculin test }\end{array}$ & $\begin{array}{l}\text { Foreign workers } \\
\text { (Asylum seekers) }\end{array}$ & At entrance & $\begin{array}{l}\text { Contacts } \\
\text { Children Adults }\end{array}$ & $\begin{array}{l}\text { Mandatory for } \\
\text { physicians }\end{array}$ \\
\hline Belgium & Active & Radiography & $\begin{array}{l}\text { Asylum seekers } \\
\text { Foreign workers }\end{array}$ & At entrance & $\begin{array}{l}\text { Fibrotic } \\
\text { lesions }\end{array}$ & $\begin{array}{l}\text { Mandatory for } \\
\text { physicians }\end{array}$ \\
\hline $\begin{array}{l}\text { Czech } \\
\text { Republic }\end{array}$ & Active & $\begin{array}{l}\text { Radiography } \\
\text { Tuberculin test }\end{array}$ & $\begin{array}{l}\text { All entering } \\
\text { foreigners }\end{array}$ & Before residence & $\begin{array}{l}\text { Contacts } \\
\text { Children }\end{array}$ & $\begin{array}{l}\text { Mandatory for } \\
\text { physicians }\end{array}$ \\
\hline Denmark & Passive & & & & Not used & $\begin{array}{l}\text { Mandatory for } \\
\text { physicians }\end{array}$ \\
\hline Finland & Active & Radiography & $\begin{array}{l}\text { Asylum seekers } \\
\text { Foreign workers }\end{array}$ & At entrance & Children & $\begin{array}{l}\text { Mandatory for } \\
\text { physicians and } \\
\text { laboratories }\end{array}$ \\
\hline France & Active & Radiography & $\begin{array}{l}\text { All entering } \\
\text { foreigners }\end{array}$ & At entrance & Children & $\begin{array}{l}\text { Mandatory for } \\
\text { physicians }\end{array}$ \\
\hline Germany & Active & $\begin{array}{l}\text { Radiography } \\
\text { Tuberculin test } \\
\text { in children }\end{array}$ & $\begin{array}{l}\text { Asylum seekers } \\
\text { (Foreign workers) }\end{array}$ & $\begin{array}{l}\text { At entrance } \\
\text { (asylum seekers) } \\
\text { Before residence } \\
\text { (foreign workers) }\end{array}$ & $\begin{array}{l}\text { (Children) } \\
\text { (Adults }\end{array}$ & $\begin{array}{l}\text { Mandatory for } \\
\text { physicians and } \\
\text { laboratories }\end{array}$ \\
\hline Greece & Active & $\begin{array}{l}\text { Radiography } \\
\text { (Tuberculin test) }\end{array}$ & $\begin{array}{l}\text { Asylum seekers } \\
\text { Foreign workers }\end{array}$ & $\begin{array}{l}\text { At entrance } \\
\text { Before employment }\end{array}$ & $\begin{array}{l}\text { Contacts } \\
\text { Children }\end{array}$ & $\begin{array}{l}\text { Mandatory for } \\
\text { physicians }\end{array}$ \\
\hline Hungary & Active & Radiography & $\begin{array}{l}\text { Asylum seekers } \\
\text { Foreign workers }\end{array}$ & At entrance & Not used & $\begin{array}{l}\text { Mandatory for } \\
\text { physicians }\end{array}$ \\
\hline Iceland & Active & $\begin{array}{l}\text { Radiography } \\
\text { Tuberculin test }\end{array}$ & $\begin{array}{l}\text { All entering } \\
\text { foreigners }\end{array}$ & $\begin{array}{l}\text { At entrance } \\
\text { Before residence }\end{array}$ & $\begin{array}{l}\text { Children } \\
\text { Adults }\end{array}$ & $\begin{array}{l}\text { Mandatory for } \\
\text { physicians and } \\
\text { laboratories }\end{array}$ \\
\hline Ireland & Passive & $\begin{array}{l}\text { Radiography } \\
\text { Tuberculin test }\end{array}$ & $\begin{array}{l}\text { All entering } \\
\text { foreigners }\end{array}$ & Variable & $\begin{array}{l}\text { Children } \\
\text { Adults }\end{array}$ & $\begin{array}{l}\text { Mandatory for } \\
\text { physicians }\end{array}$ \\
\hline Italy & Active & Radiography & Foreign workers & At entrance & $\begin{array}{l}\text { Children } \\
\text { Adults }\end{array}$ & $\begin{array}{l}\text { Mandatory for } \\
\text { physicians }\end{array}$ \\
\hline Israel & Active & $\begin{array}{l}\text { Radiography } \\
\text { Tuberculin test }\end{array}$ & Some immigrants & After entrance & Contacts & $\begin{array}{l}\text { Mandatory for } \\
\text { physicians }\end{array}$ \\
\hline Luxembourg & Active & $\begin{array}{l}\text { Radiography } \\
\text { Tuberculin test }\end{array}$ & $\begin{array}{l}\text { All entering } \\
\text { foreigners }\end{array}$ & $\begin{array}{l}\text { At entrance } \\
\text { Before residence }\end{array}$ & $\begin{array}{l}\text { Contacts } \\
\text { Children }\end{array}$ & $\begin{array}{l}\text { Mandatory for } \\
\text { physicians and } \\
\text { laboratories }\end{array}$ \\
\hline Netherlands & Active & $\begin{array}{l}\text { Radiography } \\
\text { (Tuberculin test) }\end{array}$ & $\begin{array}{l}\text { Asylum seekers } \\
\text { Foreign workers }\end{array}$ & $\begin{array}{l}\text { At entrance } \\
\text { Before residence }\end{array}$ & $\begin{array}{l}\text { Contacts } \\
\text { Children }\end{array}$ & Mandatory \\
\hline Norway & Active & $\begin{array}{l}\text { Radiography } \\
\text { Tuberculin test }\end{array}$ & $\begin{array}{l}\text { All entering } \\
\text { foreigners }\end{array}$ & $\begin{array}{l}\text { After entrance } \\
\text { Before residence }\end{array}$ & No policy & $\begin{array}{l}\text { Mandatory for } \\
\text { physicians and } \\
\text { laboratories }\end{array}$ \\
\hline Poland & Passive & & & & & \\
\hline Portugal & Active & $\begin{array}{l}\text { Radiography } \\
\text { Tuberculin test }\end{array}$ & $\begin{array}{l}\text { Asylum seekers } \\
\text { Foreign workers }\end{array}$ & $\begin{array}{l}\text { At entrance } \\
\text { Before residence }\end{array}$ & $\begin{array}{l}\text { Contacts } \\
\text { Children }\end{array}$ & $\begin{array}{l}\text { Mandatory for } \\
\text { physicians }\end{array}$ \\
\hline $\begin{array}{l}\text { Slovak } \\
\text { Republic }\end{array}$ & Active & $\begin{array}{l}\text { Radiograpy } \\
\text { Tuberculin test }\end{array}$ & $\begin{array}{l}\text { All entering } \\
\text { foreigners }\end{array}$ & At entrance & $\begin{array}{l}\text { Contacts } \\
\text { Children } \\
\text { Adults }\end{array}$ & $\begin{array}{l}\text { Mandatory for } \\
\text { physicians }\end{array}$ \\
\hline Slovenia & Active & $\begin{array}{l}\text { Radiography } \\
\text { Tuberculin test }\end{array}$ & $\begin{array}{l}\text { All entering } \\
\text { foreigners }\end{array}$ & At entrance & $\begin{array}{l}\text { Children } \\
\text { Adults }\end{array}$ & $\begin{array}{l}\text { Mandatory for } \\
\text { physicians and } \\
\text { laboratories }\end{array}$ \\
\hline Spain & Active & $\begin{array}{l}\text { Radiography } \\
\text { Tuberculin test }\end{array}$ & & & $\begin{array}{l}\text { Contacts } \\
\text { Children } \\
\text { Adults }\end{array}$ & \\
\hline Sweden & Active & $\begin{array}{l}\text { Tuberculin test } \\
\text { Radiography }\end{array}$ & $\begin{array}{l}\text { Asylum seekers } \\
\text { Some foreign } \\
\text { workers }\end{array}$ & At entrance & & $\begin{array}{l}\text { Mandatory for } \\
\text { physicians, } \\
\text { voluntary for } \\
\text { laboratories }\end{array}$ \\
\hline Switzerland & Active & $\begin{array}{l}\text { Radiography } \\
\text { (Tuberculin test) }\end{array}$ & $\begin{array}{l}\text { All entering } \\
\text { foreigners outside } \\
\text { EU and EFTA*, } \\
\text { North America, } \\
\text { New Zealand and } \\
\text { Australia }\end{array}$ & $\begin{array}{l}\text { At entrance } \\
\text { Before residence }\end{array}$ & $\begin{array}{l}\text { Contacts } \\
\text { Children } \\
\text { Adults }\end{array}$ & $\begin{array}{l}\text { Mandatory for } \\
\text { physicians and } \\
\text { laboratories }\end{array}$ \\
\hline $\begin{array}{l}\text { United } \\
\text { Kingdom }\end{array}$ & Active & Radiography & $\begin{array}{l}\text { All entering } \\
\text { foreigners }\end{array}$ & $\begin{array}{l}\text { At entrance } \\
\text { Before residence }\end{array}$ & $\begin{array}{l}\text { Children } \\
\text { Adults }\end{array}$ & $\begin{array}{l}\text { Mandatory for } \\
\text { physicians } \\
\text { (Laboratories) }\end{array}$ \\
\hline
\end{tabular}

*: EU European Union; EFTA: European Free Trade Association. 
a positive test result reflects the true presence of the condition sought, is dependent on these two characteristics of the test, but crucially on a third, the prevalence of the condition. The value of screening is improved if the condition has a high prevalence in the population which is to be screened. The two major screening tools in tuberculosis control, chest radiography and tuberculin skin-testing, have a relatively high sensitivity but limited specificity in discovering pulmonary tuberculosis or infection with $M$. tuberculosis, respectively. The implementation of a screening programme for tuberculosis must, thus, be measured in terms of rewards and predictable damage that might be done by the screening itself [16]. It is apparent that considerations, e.g. sideeffects and inconvenience due to radiation or tuberculintesting, respectively, must be taken into account when deciding whether or not to screen a particular segment of the population by radiography and/or tuberculintesting.

To make a rational decision on which groups are to be screened for tuberculosis, availability of surveillance data identifying particularly high incidence groups is mandatory.

It is important to decide on what the aim of a screening programme should be. In tuberculosis control, two major groups may be targeted for screening activities: firstly, persons with a high risk of tuberculosis in need of curative treatment; and secondly, persons at high risk of developing tuberculosis who may profit from preventive intervention. The second group includes persons with $M$. tuberculosis infection eligible for preventive therapy and uninfected children who could benefit from BCG vaccination. It is the Task Force's conviction that the discovery of tuberculosis among foreigners during screening should result in provision of effective treatment, which only few foreigners from low income countries may have had available in their country of origin. The aim is to guarantee for the foreigners equal rights for health, and by no means to use the screening programme for rejection from entrance or expelling and repatriating them to their country of origin.

Before implementing a screening programme, it must first be decided which groups are particularly likely to have a sufficiently highly prevalent condition (tuberculosis or asymptomatic infection with tubercle bacilli) that merits early intervention. It must then be decided which intervention to choose: tuberculin skin-testing, radiographic screening, either one or both, and if both, sequentially or simultaneously.

\section{Detection of cases with tuberculosis}

Radiographic examination of the chest is a sensitive and the most practical approach to discover abnormalities compatible with tuberculosis of the respiratory tract. The examination may be performed with a full-size radiograph or, if conforming to current standards for radiation exposure, with a miniature radiograph. Radiography is a sensitive tool to reveal abnormalities, but it has much less specificity in identifying the nature of a particular radiographic abnormality [17]. In such cases, examination of sputum for mycobacteria by direct microscopy and culture is always indicated.

Active screening among foreigners is best implemented before all subjects are dispersed in the country. Screening for tuberculosis is, thus, best done shortly before or after arrival in order to prevent unnecessary transmission within the group concerned, and consideration should be given for its implementation in specifically designed centres. Nevertheless, some countries may choose to delegate the screening to local health authorities in order to more efficiently utilize existing infrastructures, but screening should always encompass an evaluation.

In terms of need for public health and medical action, a simplified coding of radiographic findings may be utilized. It consists of three codes: the first denoting the degree of urgency $(0=$ no urgency; $1=$ abnormality and need for further examination; $2=$ urgent evaluation needed); the second referring to the radiographically most likely diagnosis ( $\mathrm{N}=$ normal; $\mathrm{A}=$ anomaly of technical nature; $\mathrm{P}=$ pathology other than tuberculosis; $\mathrm{T}=$ abnormality compatible with tuberculosis); and the third is a description of the anomaly. For instance: $2 \mathrm{~T}$ would indicate urgent evaluation needed for suspected tuberculosis; $2 \mathrm{P}$ a disease other than tuberculosis needing urgent medical evaluation; 1T fibrotic lesions suspect of past tuberculosis. This coding would allow health administrators (codes $0,1,2)$ and physicians (codes $\mathrm{N}, \mathrm{A}, \mathrm{P}, \mathrm{T}$ ) to learn quickly when to intervene and what examinations to perform, respectively. The third element of the coding is simply descriptive, e.g. "right upper lobe infiltrate". Thus, "2T right upper lobe infiltrate" would indicate that the person has a condition needing urgent attention, being compatible with tuberculosis in the right upper lobe of the lung.

An evaluation of the value of screening foreign populations by miniature radiography and follow-up of suspects in Switzerland has clearly identified asylum seekers from Africa, and migrant workers and asylum seekers from Turkey and Yugoslavia to have an excessive prevalence of tuberculosis compared to, e.g. Western Europeans [18] (fig. 1), indicating that such groups with a high prevalence might be ideally suited for efficient screening. Similarly, in The Netherlands, radiographic screening of asylum seekers yielded about 200 bacteriologically confirmed cases per 100,000 population [19].

\section{Identification of persons at high risk of developing tuber- culosis}

Among asymptomatic persons with pre-existing infection with $M$. tuberculosis, the three most important factors for allowing progression from subclinical, latent infection to overt tuberculosis are infection with human immunodeficiency virus (HIV), fibrotic lesions, and recent infection [20]. A tuberculin skin test is a prerequisite for the identification of these groups, and is a useful indicator of need of radiographic examination. However, in some circumstances where persons, e.g. refugees and asylum seekers, may be lost to follow-up, 


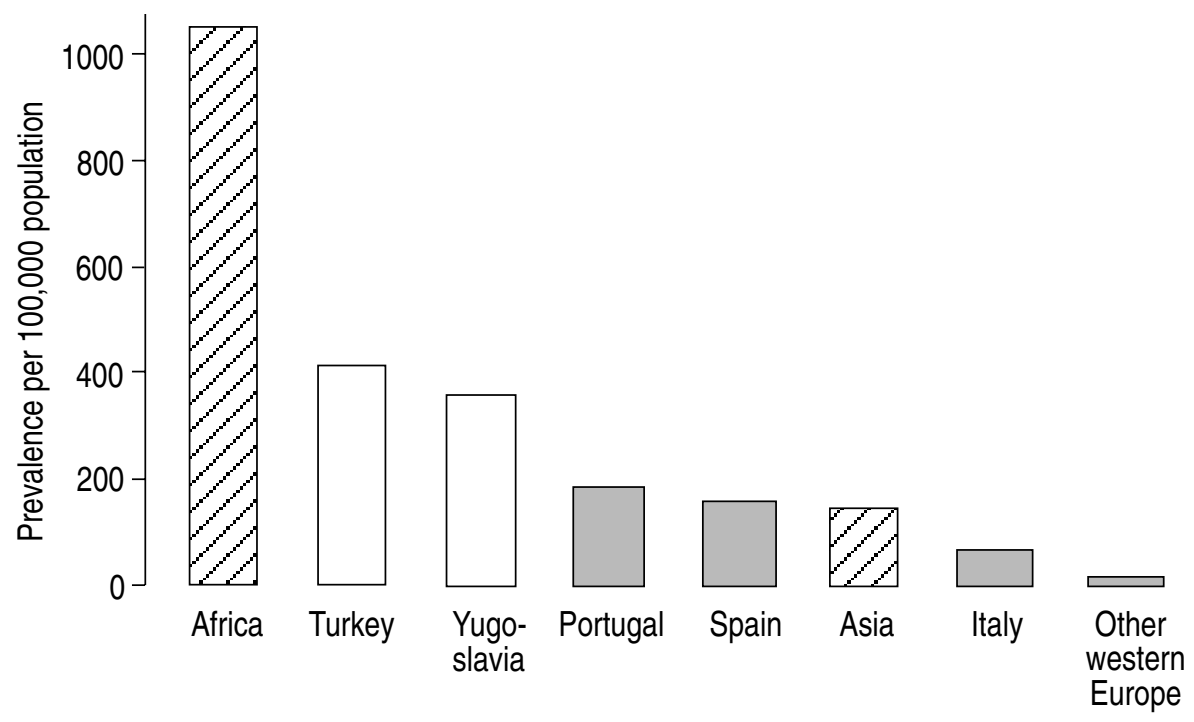

Fig. 1. - Prevalence of radiographically active tuberculosis at screening of migrant workers and asylum seekers in Switzerland, 1988-1990, by country of origin and immigration status [18]. $\square$ : migrant workers only; $\square$ : asylum seekers only.

radiographic examination is the preferred initial screening method.

It is the World Health Organization's policy that an HIV test is not warranted as part of the screening of foreigners [21]. Nevertheless, persons known for other reasons to be infected with HIV should be offered a tuberculin skin test and preventive chemotherapy if found to be dually infected [22].

Asymptomatic patients with fibrotic lesions on chest radiography and negative sputum cultures have an elevated risk of once again developing active tuberculosis [23-25]. A significant tuberculin skin test reaction will add to the probability that the visualized lesion is of tuberculous nature. An asymptomatic person with fibrotic lesions should be considered for preventive chemotherapy, once active tuberculosis has been carefully ruled out.

There is evidence that size of the tuberculin reaction strongly correlates with the subsequent risk of developing tuberculosis [26]. Small tuberculin skin test reactions might be attributable to the influence of nonspecific reactions induced by environmental mycobacteria or previous BCG vaccination [27], or both. Young persons with strong reactions and no evidence of clinically or radiologically active tuberculosis may benefit from preventive therapy. This benefit may considerably exceed the risk of drug-associated adverse reactions [28].

Finally, a nonsignificant tuberculin skin test reaction in a child coming to a European country from a high prevalence country is almost universally accepted to be an indication for vaccination with BCG. The experiences from Sweden indicate that children born to foreign parents continue to benefit from a single BCG vaccination [29]. In addition, large numbers of asylum seekers in Western Europe are refused asylum and are repatriated to their country of origin where BCG vaccination is usually a recommended mass intervention.

\section{Curative and preventive interventions}

The identification and effective treatment of patients with active tuberculosis is the most important intervention in tuberculosis control [30-32]. Treatment of tuberculosis in patients should be for 6 months with isoniazid and rifampicin throughout, supplemented by pyrazinamide and ethambutol during the first two months [33]. Directly observed therapy is recommended in some countries, but is especially important in patients where problems with compliance are anticipated [30].

Preventive therapy is an inefficient tool if used indiscriminately, because a large number of persons needs to be treated to prevent a single case $[34,35]$. The efficiency can be markedly improved by targeting infected groups at high risk of tuberculosis [20]. There is broad consensus that persons co-infected with HIV, persons with fibrotic lesions, or persons with recent infection with $M$. tuberculosis are at increased risk of developing tuberculosis. In these groups, preventive therapy is warranted [5]. Fibrotic lesions are common among immigrants, and most have not been adequately treated [36]. The increased risk of tuberculosis among immigrants with fibrotic lesions can be substantially reduced by the provision of preventive therapy [37]. Furthermore, persons with large tuberculin skin test reactions, but no other signs of past or current tuberculosis, and who have never been treated before, are also at increased risk of tuberculosis [26] and may benefit from preventive therapy. Adherence to treatment is likely to be lower among clinically healthy persons than among those with active disease. Counselling of patients and clear explanations of screening findings and the proposed medical intervention is vital to increase patient awareness and adherence. The recommended regimen for preventive therapy is 612 months of isoniazid [38]. Careful exclusion of active tuberculosis is essential before starting preventive therapy. 
Screening procedures detect only a minority of the cases of tuberculosis occurring among immigrants in the first few years after arrival. Information about the increased risk of tuberculosis, and the need to seek medical advice for respiratory symptoms, should be given to all new immigrants. Such information should be culturally and linguistically appropriate.

\section{Follow-up of implementation of indicated interventions}

Unfortunately, it is in the nature of screening programmes that they are relatively easily implemented, but more difficult to follow up and to carry through interventions [16]. A screening programme without followup should not be implemented, and, if carried out, results of follow-up should be documented and audited. Followup might prove difficult due to cultural and language barriers, and other factors [38]. However, precisely because of such factors, it is particularly important to ensure that recommended interventions are adhered to both by the physician in charge and the patient. Many countries do still have a network of nongovernmental organizations, such as respiratory disease associations, that are well-suited to co-operate with public health authorities and private physicians in follow-up. In tuberculosis, directly observed therapy must be seriously considered to ensure completion of prescribed treatment regimens [30], because compliance or nonadherence to prescriptions are not easily predictable [39, 40].

\section{Legal issues}

Legal provisions that prevail in different European countries may allow them to address the problems raised in this position paper to a varying extent. It is not the intent of the Task Force to fundamentally challenge such existing laws and regulations, but rather to outline elements of surveillance and measures of control that are desirable from a public health point of view. Individual European countries may need to adjust specific recommendations to their proper needs and possibilities within an existing legal framework.

\section{Outlook and recommendations}

Tuberculosis is a global problem. Tuberculosis interventions to interrupt transmission and to prevent unnecessary morbidity and mortality are widely available. With increased international migration, its high incidence and prevalence in most low income countries is increasingly being mirrored in the epidemiology of tuberculosis in Europe and other industrialized countries. Whilst the pace of disappearance of tuberculosis among the indigenous population of industrialized European countries may not be importantly affected by immigration of foreigners, it is imperative to maintain expertise in identifying and curing tuberculosis among all strata of a given society. Screening programmes for high incidence groups and determined application of available intervention strategies can be successful in reducing the problem among migrant workers [18] and other categories of foreigners.

Routine surveillance of tuberculosis and epidemiological analysis are essential requirements to identify high incidence groups that could benefit individually and improve the situation from a public health point of view.

The Task Force agreed upon the following recommendations that should be considered in all countries of Europe.

Notification. The ideal notification system will require both laboratories and physicians to report each case of tuberculosis in such a way that each patient can be traced. Laboratory reports should be supplemented with demographic information obtained from physicians. Cases should be reported individually and be computerized.

Surveillance. Notified cases should be analysed on an ongoing basis, to allow the identification of deviations from the expected baseline course and to target newly emerging groups with an increased incidence of tuberculosis. Epidemiological analysis should identify groups at higher risk of tuberculosis than the general population.

Screening. Screening may be targeted at identifying cases of tuberculosis among groups at excess risk of tuberculosis identified in surveillance, persons subclinically infected with $M$. tuberculosis meriting further investigation and intervention, or both.

Implementation of intervention strategies. Pre-existing structures (e.g. governmental and nongovernmental organizations) should include access to culturally and socially sensitive services to ensure proper follow-up of persons needing intervention. The initial treatment of a tuberculosis patient should include isoniazid, rifampicin, pyrazinamide and ethambutol for 2 months, and, if the strain is found to be susceptible, the continuation phase should consist of 4 months isoniazid and rifampicin. Preventive chemotherapy should consist of 6-12 months of isoniazid, after currently active tuberculosis has been ruled out.

Financing. Public health warrants that the government should take direct responsibility for screening and pay for its costs. Financing mechanisms must implicitly provide for comprehensive curative or preventive services to treat tuberculosis.

Evaluation. Screening procedures must remain subject to ongoing evaluation of efficiency and efficacy, and yield from screening should be weighed against its cost on a regular basis.

\section{Members of the Task Force}

J. Bushati (Albania); H. Halbich-Zankl (Austria); V.P. Filonov (Belarus); J-M. Verstraeten (Belgium); I. Gjenero 
Margan (Croatia); L. Trnka (Czech Republic); G. Pallisgaard (Denmark); P.D.O. Davies, J. Watson (England and Wales); K. Liippo, E. Tala (Finland); V. Schwoebel (France); M. Forssbohm (Germany); N.E. Yatromanolakis (Greece); D. Kozma, I. Vadász (Hungary); T. Blöndal (Iceland); L. Clancy, P. Kelly (Ireland); D. Weiler (Israel); G.B. Migliori, M.L. Moro (Italy); D. Gaidamoniene (Lithuania); G. Molitor (Luxembourg); D. Sain (Moldova); S.T. Keizer, J. Veen (The Netherlands); K. Bjartveit (Norway); E. Mitchell (Northern Ireland); J. Leowski, M. Pirozynski (Poland); M.L. Antunes (Portugal); C. Didilescu (Romania); A.G. Khomenko (Russia); A.G. Leitch (Scotland); A. Bajan (Slovak Republic); J. Sorli (Slovenia); J. Alcaide, R. Rey (Spain); V. Romanus (Sweden); H. Siem, P. Spenning (International Organization for Migration); J-P. Zellweger (Switzerland and International Union Against Tuberculosis And Lung Disease Europe Region); A. Kochi, M.C. Raviglione, S. Spinaci (World Health Organization); D.A. Enarson, H.L. Rieder (International Union Against Tuberculosis and Lung Disease).

\section{References}

1. World Health Organization Regional Office for Europe. In: Colledge M, van Geuns HA, Svensson PG, eds. Migration and health: towards an understanding of the health care needs of ethnic minorities. Proceedings of a consultative group on ethnic minorities, The Hague, The Netherlands, 28-30 November 1983. WHO Regional Office for Europe, Copenhagen, 1983.

2. International Union Against Tuberculosis. Scientific Meeting II (Lundquist J, chairman). Tuberculosis in immigrants and foreign workers. Bull Int Union Tuberc 1965; 36: 105-141.

3. World Health Organization Regional Office for Europe. Tuberculosis among migrant workers. Report on a working group, Bern 22-24 April 1975. WHO Regional Office for Europe, Copenhagen, 1975.

4. Raviglione MC, Sudre P, Rieder HL, Spinaci S, Kochi A. Secular trends of tuberculosis in western Europe. Bull WHO 1993; 71: 297-306.

5. Clancy L, Rieder HL, Enarson DA, Spinaci S. Tuberculosis elimination in the countries of Europe and other industrilized countries. Based on a workshop held at Wolfheze, The Netherlands, 4-9 March 1990, under the joint auspices of the IUATLD (European region) and WHO. Eur Respir J 1991; 4: 1288-1295.

6. Menzies R. Tuberculin sensitivity among school children in Montreal. Tuberculosis Surveillance Research Unit of the IUATLD, Progress Report 1991, Vol. 1. The Hague, K.N.C.V., 1991; pp. 121-151.

7. Rieder HL, Cauthen GM, Kelly GD, Bloch AB, Snider DE Jr. Tuberculosis in the United States. J Am Med Assoc 1989; 262: 385-389.

8. Grzybowski S, Barnett GD, Styblo K. Contacts of cases of active pulmonary tuberculosis. Bull Int Union Tuberc 1975; 50: 90-106.

9. van Geuns HA, Meijer J, Styblo K. Results of contact examination in Rotterdam. 1967-1969. Bull Int Union Tuberc 1975; 50: 107-121.

10. Liippo KK, Kulmala K, Tala EOJ. Focusing tuberculosis contact tracing by smear grading of index cases. Am Rev Respir Dis 1993; 148: 235-236.
11. Raviglione MC, Rieder HL, Styblo K, Khomenko AG, Esteves K, Kochi A. Tuberculosis trends in eastern Europe and the former USSR. Document WHO/TB/94.176. Geneva, World Health Organization, 1994.

12. Rieder HL. Misbehaviour of a dying epidemic: a call for less speculation and better surveillance. (Editorial). Tuberc Lung Dis 1992; 73: 181-183.

13. Schweizerischer Bundesrat/Conseil fédéral suisse. Verordnung über die Meldung übertragbarer Krankheiten des Menschen (Meldeverordnung) vom 21. September 1987, SR 818.141.1 / Ordonnance concernant la déclaration des maladies transmissibles de l'homme (ordonnance sur la déclaration) du 21 septembre 1987, RS 818.141.1.

14. The National Bacteriological Laboratory/The Swedish Heart Lung Foundation. The Swedish Tuberculosis Index 1989 and 1990. Stockholm, SBL/Hjärt-Lungfonden, $1993 ; 21$.

15. Wallace RB, Everett GD. The prevention of chronic illness. In: Last JM, ed. Public Health and Preventive Medicine. 12th edn. Norwalk, Connecticut, AppletonCentury-Crofts, 1986; pp. 1125-1132.

16. Skrabanek P, McCormick J. In: Follies and Fallacies in Medicine. Glasgow, Tarragon Press, 1989.

17. Nyboe J. Results of the international study on X-ray classification. Bull Int Union Tuberc 1968; 41: 115-124.

18. Bundesamt für Gesundheitswesen/Office fédéral de la santé publique. Die grenzsanitarische Schirmbilduntersuchung bei ausländischen Arbeitnehmern und Asylbewerbern/Examen radiophotographique sanitaire de frontière chez les travailleurs étrangers et les requérants d'asile, 1982-1991. Bull BAG/OFSP (Switzerland) 1993; 30: 540-545/35: 644.

19. Keizer ST, Broekmans JF, Bilkert-Mooiman MAJ. Tuberculosis among asylum seekers and immigrants in The Netherlands. (Abstract). Eur Respir J 1992; 5 (Suppl. 15), p. 3045.

20. Rieder HL, Cauthen GM, Comstock GW, Snider DE Jr. Epidemiology of tuberculosis in the United States. Epidemiol Rev 1989; 11: 79-98.

21. World Health Organization. Global Programme on AIDS. Statement from the consultation on testing and counselling for HIV infection. Geneva, 16-18 November 1992. Document WHO/GPA/INF/93.2.

22. Pape JW, Jean SS, Ho JL, Hafner A, Johnson WD. Effective isoniazid prophylaxis on incidence of active tuberculosis and progression of HIV infection. Lancet 1993; 342: 268-272.

23. International Union Against Tuberculosis Committee on Prophylaxis. Efficacy of various durations of isoniazid preventive therapy for tuberculosis: five years of followup in the IUAT trial. Bull WHO 1982; 60: 555-564.

24. Falk A, Fuchs GF. Prophylaxis with isoniazid in inactive tuberculosis; a Veterans Administration co-operative study. XII. Chest 1978; 73: 44-48.

25. Edwards LB, Doster B, Livesay VT, Ferebee SH. Risk of tuberculosis among persons with "not active - not treated" lesions. Bull Int Union Tuberc 1972; 47: 151-156.

26. Edwards LB, Acquaviva FA, Livesay VT. Identification of tuberculous infected. Dual tests and density of reaction. Am Rev Respir Dis 1973; 108: 1334-1339.

27. Tuberculosis Prevention Trial, Madras. Trial of BCG vaccines in south India for tuberculosis prevention. Indian J Med Res 1980; 72 (Suppl.): 1-74.

28. Iseman MD, Miller B. If a tree falls in the middle of the forest. Isoniazid and hepatitis. (Editorial). Am Rev Respir Dis 1989; 140: 575-576. 
29. Romanus V, Svensson $\AA$, Hallander HO. The impact of changing BCG coverage on tuberculosis incidence in Swedish-born children between 1969 and 1989. Tuberc Lung Dis 1992; 73: 1500-161.

30. Iseman MD, Cohn DL, Sbarbaro JA. Directly observed treatment of tuberculosis. We can't afford not to try it. N Engl J Med 1993; 328: 576-578.

31. Kochi A. The global tuberculosis situation and the new control strategy of the World Health Organization. (Leading article). Tubercle 1991; 72: 1-6.

32. Sutherland I. The epidemiology of tuberculosis: is prevention better than cure? Bull Int Union Tuberc 1981; 56: $127-134$.

33. World Health Organization. Treatment of tuberculosis. Guidelines for national programmes. Geneva, World Health Organization, 1993.

34. Anonymous. Chemoprophylazis for tuberculosis. (Leading article). Tubercle 1981; 62: 69-72.
35. Snider DE Jr, Farer LS. Preventive therapy for tuberculous infection: an intervention in need of improvement. (Editorial). Am Rev Respir Dis 1984; 130: 355-356.

36. Bonvin L. Zellweger JP. Mass miniature X-ray screening for tuberculosis among immigrants entering Switzerland. Tuberc Lung Dis 1992; 73: 322-325.

37. Nolan CM, Elarth AM. Tuberculosis in a cohort of south east Asian refugees. A five year surveillance study. Am Rev Respir Dis 1988; 137: 805-809.

38. Snider DE Jr, Caras GJ, Koplan JP. Preventive therapy with isoniazid. Cost-effectiveness of different durations of therapy. J Am Med Assoc 1986; 255: 1579-1583.

39. Snider DE Jr, Hutton MD. Improving patient compliance in tuberculosis treatment programs. Atlanta; Centers for Disease Control, 1986.

40. Sumartojo E. When tuberculosis treatment fails. A social behavioral account of patient adherence. Am Rev Respir Dis 1993; 147: 1311-1320. 